\title{
Medium, Small and Medium Enterprises and Digital Platforms
}

MSMEs in Indonesia have the opportunity to contribute to a Gross Domestic Product of USD 140 billion or around IDR 2.052 trillion in 2030 (Tayibnapis \& Wuryaningsih, 2021). However, Every micro, small and medium entrepreneur is required to be able to personalize their digital tools and make themselves open to the communities they need. Small and Medium Enterprises are classified as micro business groups with assets of not more than IDR 50 million and a maximum turnover of IDR 300 million/year. MSME recovery cannot be separated from the use of information technology, considering that digitalization is the key for business actors to be able to survive and develop amid the Covid 19 pandemic. So far the number of business actors who have entered the digital ecosystem is still relatively small. This means that solutions and innovation are urgently needed for digitizing MSMEs. However, the process of digitizing MSMEs cannot take place immediately and it is best to join electronic trade providers, such as Shopee and Tokopedia. Efforts to digitize MSMEs need to be maintained in various ways, including consistent and routine mentoring by e-commerce companies.

Digital technology-based financing for ultra-micro is indeed intended to accelerate penetration and inclusive finance, considering that ultra-micro business actors still have difficulty accessing bank financing due to various factors, such as not having a bank account, location that is difficult to reach, or very small business scale. There should be mutual reinforcement between MSMEs and large businesses in the context of equitable distribution and realizing the greatest possible prosperity for the entire community. The government is obliged to direct, guide, protect and foster the business climate. In addition, the capacity of MSMEs including agricultural businesses from time to time needs to be considered, given that most Indonesians live and depend their economy on this sector. Many efforts to develop and empower MSMEs have been carried out by the Central, Provincial, Regency, and City Governments, including State-owned enterprises and Regional-owned enterprises.

Republic of Indonesia (September 2020) explains that there are decrease in micro and small income business by $84 \%$ and $82 \%$ in medium and big business. Enforcement of regional restrictions have a negative impact on MSMEs, but some MSMEs continue to operate despite a decline income more than $40 \%$. MSME Recovery cannot be separated from the use of information technology, considering that digitization is key for entrepreneurs to survive and developed in the midst of the Covid-19 pandemic. However, so far the number of business actors who have entered the digital ecosystem are still relatively small. This means that the solution and innovation is needed for digitization SMEs. This means that developing frugal economy will be a strategic effort to save the national economy from the shackles of recession. Experts state that small traders are business actors with relatively small capital who carry out production activities or sell goods and services to meet the needs of certain groups in society.

\section{Bibliography}

Tayibnapis, A. Z., \& Wuryaningsih, L. E. (2021, March 16). Medium, Small and Medium Enterprises and Digital Platforms. outh Asian Journal of Social Studies and Economics, 10-19. doi:10.9734/sajsse/2021/v10i230258 